University of New Haven

University of

New Haven

Digital Commons@ New Haven

Sociology Faculty Publications

Sociology

8-29-2018

Beyond the Local: Places, People, and Brands in New England Beer Marketing

Jeffrey S. Debies-Carl

Follow this and additional works at: https://digitalcommons.newhaven.edu/sociology-facpubs C. Part of the Sociology Commons

\title{
Comments
}

This is the author's accepted version of the article published in Journal of Cultural Geography. The version of record can be found at http://dx.doi.org/ $10.1080 / 08873631.2018 .1511104$ 


\title{
Beyond the local:
}

\section{Places, people, and brands in New England beer marketing}

\author{
Jeffrey S. Debies-Carl, Ph.D.* \\ Associate Professor of Sociology \\ University of New Haven
}

Keywords: Beer; branding; advertising; neolocalism; place; authenticity Word Count: 11,648

\footnotetext{
* Please direct correspondence to Jeffrey S. Debies-Carl, University of New Haven, Department of Psychology and Sociology, 300 Boston Post Road, 308 Harugari Hall, West Haven, CT 06516. Phone: (203) 479-4983, Email: jdebiescarl@ newhaven.edu.

Acknowledgments: This work was funded in part by a summer research grant by a summer research grant from the University of New Haven. I would like to thank Matthew Wranovix for his help in locating an elusive observation for the data.
} 


\title{
Beyond the local:
}

\section{Places, people, and brands in New England beer marketing}

\begin{abstract}
Despite decades of domination by a few large companies, the American beer market has seen a dramatic resurgence of microbreweries. Contrary to conventional oligopolistic market theories, small firms have consistently gained market share from their entrenched competitors. Researchers have attributed this success to 'neolocalism.' Through their marketing, microbreweries appeal to consumers' desire for connections to real people and distinctive products from local places. However, no study has verified whether this pattern is most characteristic of microbreweries. With newer firms threatening their market share, larger firms might adopt neolocal claims, but little empirical attention has been directed at large brewers, and mid-sized, regional firms have been largely ignored by researchers. This paper uses content analysis of beer packaging to investigate the nature of the appeals made to consumers. I find that while microbreweries do make neolocal claims, regional breweries are more likely to associate their products with places on a local scale. Large breweries make few such claims, but instead rely on 'reflexive branding': marketing that refers back to the brand itself rather than borrowing existing symbolism from people or places. These findings partly support the neolocal perspective, but also challenge our expectations of which firms use neolocal appeals the most.
\end{abstract}




\section{From microbreweries to megabreweries and back again}

Recent years have witnessed remarkable growth in the popularity of microbreweries in the US. Considerable research has explored the appeal these small breweries hold for consumers and provided several possible explanations. However, most of this research has been directed at microbreweries themselves. It remains to be seen whether these patterns are really distinct to them, or if similar patterns occur among larger brewers as well. The current study contributes to our understanding of microbrewery appeal, and therefore also to issues of identity and culture linked to that appeal, by systematically comparing marketing techniques across brewery types to determine what differences exist across them. Before turning to this comparison, it is important to first understand the history of the beer market and the remarkable shifts it has experienced over the years.

Beer has been an important part of American life since its early years as a colony. Colonists saw beer as essential for survival. It was safer than water, which was frequently contaminated by deadly pathogens like cholera, and more filling to boot (Smith 1998). For these reasons, breweries were widespread. Often, local governments encouraged the establishment of taverns (which also served as inns) and breweries, considering them essential to the economic and social health of a colony and beer itself essential to the health of individuals. A brewery was among the first structures built when a new colony was founded, and these multiplied as colonies grew. The precise number of breweries in existence during these early years is unknown since, in addition to formally licensed breweries, many taverns brewed their own product (Smith 1998).

Beer would eventually become big business in America, with production constantly expanding. The overall number of breweries grew until the early $20^{\text {th }}$ century. Prohibition, followed by a catastrophic economic depression, forced many out of business and ultimately led 
to the centralization of the beer market among a few major brewers. Those that managed to stay open during prohibition did so largely by diversifying into other ventures (Ogle 2006). Yuengling for example, America's oldest extant brewery, preserved its fortune by investing in everything from gold mines to ice cream. However, diversification takes capital, so larger breweries were more likely to survive (Smith 1998, Yenne 2003). Some 1,000 brewers existed in 1918. By 1933, when prohibition was repealed, about half remained (Ogle 2006). These breweries nonetheless faced continued poor economic conditions and decreased public consumption. For these reasons, many breweries continued to close in the decades following prohibition, but other developments would present additional problems to the already beset smaller firms.

Innovations in packaging and shipping also contributed to market consolidation. Refrigeration and new cheap, light-weight cans allowed some companies to expand their distribution across the country. This new emphasis on the national marketplace "exacerbated small brewers' woes and inadvertently fueled the dynamic that favored giant breweries" (Ogle 2006, p.217). By 1978, only 41 companies remained. However, this pattern reversed dramatically over the following years with small breweries proliferating. By 2013, over 2,400 breweries were in operation (Brewers Association 2013) and by 2017, some 5,300 (Brewers Association 2016a). Of these, most are small breweries. ${ }^{1}$ Despite little capital, small distribution areas, and modest market shares, small breweries are no longer being shut out by the major breweries - indeed, they are thriving.

The remarkable growth in small breweries and consumer demand has led many to describe the current era as a "microbrew revolution" (Yenne 2003). Overall, beer sales in the

\footnotetext{
${ }^{1}$ Based on the Brewers Association's classification (2016c), which defines 'micro' breweries as those firms producing fewer than 15,000 barrels per year.
} 
United States have declined in market share relative to other alcoholic beverages. From 2000 to 2011, beer's share (in dollars) shrank from 55\% to 49\%, whereas wine and spirits grew over this period (16\% to $17 \%$ and $29 \%$ to $34 \%$, respectively) (Demeter Group 2013). However, the majority of this shrinkage is attributable to many consumers shunning beverages from the larger breweries (such as Anheuser-Busch and Coors). By contrast, many small breweries are experiencing strong growth. These breweries remain minor players compared to the large breweries, but their profit margin is often higher and their market share has steadily increased. In 2010 , craft beer accounted for $4.9 \%$ of US beer sales by volume sold and $7.6 \%$ by dollars spent. These figures grew in just two years to $6.5 \%$ market share by volume and $10.2 \%$ by dollars in 2012 (Brewers Association, 2013). In 2017, they continued to rise to $12.7 \%$ market share by volume and $23 \%$ by dollars (Brewers Association 2018). The craft market remains strong and continues to expand, although its rate of growth has slowed significantly (Terazono 2018).

\section{Big growth among small brewers}

At the same time as small breweries have proliferated, the American beer market has simultaneously become further consolidated among a few, large companies. In 2017, there were 5,648 breweries operating in the United States ( Alcohol and Tobacco Tax and Trade Bureau 2018). However, the majority of beer $(72.6 \%)$ was produced by by only 15 breweries $(0.27 \%$ of the total number). It seems unlikely that new breweries could elbow into this tight market, dominated by successful, well-established brands (cf. Porter 1980), but this has occurred repeatedly. Resource-partitioning theory can explain how such consolidation counterintuitively sets the stage for the rapid growth of small brewers. 
Carroll and Swaminathan (2000) demonstrated that market concentration and small-firm growth are actually part of the same economic process. Small firms can proliferate in a market even if large firms increasingly dominate the overall market. This is because the means that permit large firms their dominance (e.g., economies of scale, appeal to a broad customer base) cannot be effectively leveraged over specialist tastes at a market's margins. The products so produced are intended to appeal to a wide, broad public, not to smaller segments of that public that are not satisfied by the type or style of beer produced. Conversely, smaller firms cannot compete using generalist methods, but they can appeal to niches unsatisfied by large firms. Through 'hyperdifferentiating' products, small firms can attract customers that are not satisfied by products designed for a general public (Clemons et al. 2006). Large companies still dominate the American market, but they cannot appeal to niches where microbreweries thrive (Baginski and Bell 2011).

The nature of the appeal of small brewers has been subject to several inquiries. Carroll and Swaminathan (2000) suggested it has to do with cultural rather than technical characteristics. Though they typically brew uniform lagers with cheap ingredients, large breweries can produce beers with physical characteristics like microbreweries. However, even when they do so, there is something about the firms themselves that specialist consumers find unappealing. The current, dominant explanation for microbrewery popularity suggests small firms resonate with some consumers' desire for 'neolocalism.' This has been described as a "self-conscious reassertion of the distinctly local" (Flack 1997, p. 38) and as "a delayed reaction to the destruction in modern America to traditional bonds to community and family" (Shortridge 1996, p.10). Flack (1997) argued neolocalism motivates support for microbreweries. Through these, consumers can 
connect with 1) local places, wherein 2) real people they can meet, 3) produce hand-crafted products.

Products from large breweries are available nearly anywhere, representing undifferentiated, mass society rather than any particular 'place,'; that is, a specific, physical location with associated meanings (Debies-Carl 2014). Microbreweries, conversely, are small and easily linked to specific places and people (Hede and Watne 2013), as are their products. Thus, "[a]t a time when the cultural and commercial landscape is becoming increasingly homogenized by national and multinational corporations, many people are actively proclaiming the difference and distinctiveness of their locales, and building a renewed sense of loyalty to those places" (Schnell and Reese 2003, p.65). According to the neolocal perspective, consuming micro-beers gives consumers a sense of place, a means of supporting local business, and a feeling of belonging to the local landscape and community. This is evidenced through various marketing practices, including product packaging. Breweries in Montana, for example, draw on the region's reputation as an outdoor paradise with "[f]ishing-, mountain-, and wildlife-themed beers" (Fletchall 2016, p.551). The places breweries associate themselves with are presented as local and specific, not homogenous landscapes (Holtkamp et al. 2016). For example, whereas a Bud Light can be found anywhere, "you cannot get a Black Radish Lager anywhere else in the world but Manteo, North Carolina” (Flack 1997, p.50), where one can visit the Weeping Radish Brewery and Restaurant: a distinctive local establishment. In short, "microbreweries are marketing 'place' as much as they are marketing beer" (Schnell 2013, p.57).

Several characteristics describe the appeal of microbreweries including: 1) their ability to provide a connection to place, 2) the sense that they represent actual people one can meet; and 3) their provision of 'authentic' beers. That is, beers that "seem real, unique, or high quality, instead 
of plastic or fake” (Koontz 2010, p.978). In this regard, Schnell argues that “ “[t]he local' is presented as a deliberate counter to 'the global,' as a sign of transparency (...), as non-corporate, as rooted in community, and, perhaps more than anything else, 'authentic'” (2011, p.283). Since brands "intentionally signal certain values to consumers via advertising" (Shepherd et al. 2015, p.85), we would expect to find these characteristics in microbrewery marketing more than in marketing from large companies. Yet, despite the popularity of the neolocal explanation, the extent to which such appeals are confined to small breweries has not been examined. Some suggest large firms can engage in the same appeals as smaller breweries, despite their size and corporate character. For example, large companies have long used branding to give consumers a sense of personal relationship with the company (Holt 2006). Brands like Betty Crocker incorporate sympathetic human traits into their names. Others, like Frosted Flakes, have likable mascots with human traits. Humanizing characteristics allow consumers to relate to brands (Aaker 1997). Similarly, when consumers want a 'real' product, "even large corporations like Starbucks and Coors attempt to fulfill consumers' desires for authenticity" (Koontz 2010, p. 977). Indeed, given their increased need to make products intimate - the original purpose of branding (Klein 1999) — we could expect larger companies to proclaim 'neolocal' or other placebased characteristics more vigorously than microbreweries precisely because they have no actual local connection.

While researchers have examined microbreweries, less empirical attention has been directed towards larger brewers - those that produce more than 6,000,000 barrels per year (Brewers Association 2016c) — and so we know less about the use of place-based appeals in their marketing. Rather, omitting larger breweries is often a purposeful methodological decision (e.g., Flack 1997, Schnell and Reese 2003, Hede and Watne 2013, Holtkamp et al. 2016, 
Mathews and Patton 2016). Some research does include large brewers (e.g., Baginski and Bell 2011, O’Neill et al. 2014), but no study has yet differentiated their marketing techniques from other types of brewers analytically. Moreover, regional brewers - those producing 15,000 6,000,000 barrels per year (Brewers Association 2016c) — are almost entirely ignored in research. Even when these are included in samples, usually researchers do not single regionals out at all, thus they have been effectively absent from scholarly consideration as distinct firms. This is unfortunate given Carroll and Swaminathan's (2000) note that regionals are precariously situated between polarized business models. Consequently, an exploration of large and regional breweries is necessary to better understand the appeal of microbreweries.

\section{Methodology}

To investigate the appeal of breweries to potential customers, I conducted a content analysis of beer packaging (i.e. beer cartons, bottle labels, and can enamel). Packaging is purposeful communication, a carrier of meaning, from the producer to consumer which "presents a product's functional and emotional benefits" (Zaltman 2003, p.205). As Carroll and Swaminathan (2010) suggest, intangibles like brand identity play an important role in the marketplace and packaging can convey those messages — an assertion verified by analysis of packaging (Patton and Mathews 2013). While previous studies represent broad exploratory investigations of place-based imagery in microbeers (e.g., Eberts 2014, Hede and Watne 2013, Schnell and Reese 2003), this study is a focused analysis that brings two new, important contributions: 1) inductive analysis of product messaging beyond appeals to place and 2) systematic comparison of messaging themes by brewer type. 


\section{Data}

The data themselves include a more holistic consideration of packaging than found in most previous research. Patrons in stores have access to the whole beer package when shopping, so I examined the entirety of such packaging instead of examining only the information available on websites (e.g., Hede and Watne 2013, Mathews and Patton 2016). Indeed, Holtkamp et al. noted that "the greatest opportunity for future research [would involve] data collection methods other than Web site review so as to gather more complete data" (2016, p.75). Full packaging contains more information than just package fronts. The only other study using full packaging was Patton and Mathews (2013), who examined maps on beer cartons. I mainly examined cartons and cans as these tend to be the primary form of packaging used. Moreover, bottles or cans within cartons tend to have redundant, abbreviated information compared to their enclosing container. However, where products only came in other packaging (e.g., over-sized bottles), I examined these instead.

The richness of the data come at the cost of a relatively small sample given the time, expense, and difficulty of accessing physical packaging. I partly made up for this through careful sample selection. A profusion of different beer brands exist today, but they are not all equally available across the country. Focusing on a single region approximates the actual product choices available to consumers in a particular marketplace, and allows a meaningful comparison of the varying appeals such products present. Thus, like previous studies (Baginski and Bell 2011, Eberts 2014, Fletchall 2016, Murray and Klein 2015), I limited the analysis to a single geographic region: New England. The concept of New England-consisting of Connecticut, Maine, Massachusetts, New Hampshire, Rhode Island, and Vermont — as a specific region with a coherent identity, is prominent in American culture. It possesses a familiar set of established 
images, traditions, and history (Feintuch and Watters 2005) that marketing can reference and consumers can be expected to recognize (e.g., Miller 2012). New England brings to mind various features supposedly distinctive to the locale such as its "accents, foodways, and musical tastes, [...] religious preferences and political tendencies" (Adams 2014: 1). The reality is of course more complicated than a simple, pleasant image conveys. Regional identity is neither singular nor stable. It changes over time and is contested even within a given era in response to shifting social and political agendas (Adams 2014). The character of New England has been under constant revision for as long as the concept of New England has existed. These revisions "typically singled out certain cultural patterns and geographic locations and excluded others in the construction of regional identity" (Conforti 2001: 2). Many of our contemporary ideas of what colonial New England was like are actually the inventions of later periods. For example, in the $19^{\text {th }}$ century, prominent historians, poets, and novelists promoted several ideas that are still popular today (Bowden 1992a). These include the claims that colonial New England was a culturally homogenous place, settled only by English Puritans, who lived in two-story houses, which were built closely together around a central village green. This conceptualization erases the "[m]emory of the 14 distinct beach-heads of six different English regional cultures" (Bowden 1992a: 17) and the fact that most New Englanders lived in one-story houses spread out over the land. It also ignores counter claims, such as the efforts of Rhode Islanders to assert an identity of their state as a refuge from Puritanism—an assertion still maintained today (Conforti 2001). Similar problems with New England identity are encountered when we consider that the images of the native peoples are similarly distorted, but in different ways depending on which narrative we read. Whether portrayed as savage animals, as romantic nature lovers, or as largely absent, traditional narratives tend to misrepresent the real people behind the story and downplay their 
contribution to history and to the shaping of the landscape (Bowden 1992b). Thus, while the political boundaries of New England are well-delineated and stable, its cultural character is another matter entirely. Nonetheless, the current idea of New England resonates in people's minds today with familiar meaning and imagery. Indeed, "this elaborated meaning" has become very successful "in attracting residents and tourists" (Wood 1997: 3). In the hopes of sharing in this success, brewers could easily borrow from the inventory of readily available images of New England to market their products. Selecting a single region also controls for differences that exist across regions (Mathews and Patton 2016). While interregional variation is important, it unnecessarily complicates the current study's goal of comparison by type of brewer, not by region.

Having selected a single region, I next identified the categories of breweries to represent in the sample. For this, I adopted the widely-used standard of the Brewers Association's typology (2016c). This classifies breweries into market segments based on annual beer production: 'large' (over 6,000,000 barrels per year), 'regional' (15,000 - 6,000,000 barrels), and 'micro' (fewer than 15,000 barrels). ${ }^{2}$ It was then necessary to assemble a suitable dataset to represent each category and enable comparison across these that a local consumer could realistically choose between. I used separate sampling procedures to represent each brewery type to account for the different characteristics of each type in the market.

Large breweries: Like most markets, the New England market continues to be saturated by products from large breweries. While many brands are available, I included only the bestselling of these since popular beers are most likely to represent the appeal of this category of

\footnotetext{
${ }^{2}$ I excluded brewpubs when their products could only be purchased on premises and, therefore, likely experience different marketing realities (Mathews and Patton 2016). Contract breweries - which do not brew but simply brand products they hire others to produce-were similarly excluded.
} 
brewers. I selected the top 20 best-selling beers in America in 2012 (DBJ Staff 2013)

representing nearly $73 \%$ of the US market share (in dollars). I supplemented this with the bestsellers of 2016 (Statista 2017). For the most part, the lists overlapped, with the 2016 figures adding three new beers. ${ }^{3}$ The final sample consisted of 22 beers. Given that these were owned by only a handful of companies, ${ }^{4}$ each beer was treated as a distinct entity analytically, regardless of affiliated company, to better represent the marketing practices of large producers.

Regional breweries: To allow a meaningful comparison to New England microbreweries, I only included regionally-sized brewers that are New England-based. Since there are so few of these, I was able to include all but one in the sample $(n=16)$, the locations of which are presented in Figure 1. ${ }^{5}$ The exception was the Geary brand, which I could not examine firsthand. Like larger breweries, regional breweries sometimes managed multiple brands as though they were from different companies. When this occurred, I again treated them as different cases (e.g., Otter Creek Brewing and Wolaver's Organic Brewing).

Microbreweries: Given their small distribution areas, microbreweries presented particular challenges for sampling. I initially attempted to draw a random sample, but frequently could not locate selected products first-hand. Instead, I took a series of trips across the region from 20122017, as part of a larger project on regional tourism, during which I collected the microbeers that were available in each destination or en route. This travel purposefully encompassed each of the New England states to maximize representativeness in the sample and yielded a total of 51

\footnotetext{
3 These included Blue Moon, Coors, and Sierra Nevada Pale Ale. Sierra Nevada was a national best-seller in 2016 , but excluded because it is regionally-sized and headquartered outside New England. Two cases were excluded because they consisted of several rotating beverages and not a single product.

${ }^{4}$ On account of mergers and exchange of brands among companies, the exact number of companies represented varies from year-to-year, but never exceeds six during 2012-2017.

${ }^{5}$ For both regional and microbreweries, each company generally produced more than one beverage. For this reason, I selected the product for analysis at random from those available at the time of sampling, comparing selected brands to the company's other brands to ensure reasonable representativeness in packaging style.
} 
observations as shown in Figure 1. It is possible that this method made it less likely that minor breweries with very small distribution ranges would be included in the sample.

\section{Content analysis}

To examine the patterns present in beer packaging, I conducted a content analysis using the grounded theory approach (Miles and Huberman 1994). Unlike deductive approaches, this inductive method does not require that the researcher first develop predetermined hypotheses for testing or categories for coding drawn from prior literature. Instead, analysis commences by attempting to create categories directly from the data themselves. This allows for a flexible analysis, responsive to emergent trends in the data since the researcher must iteratively adapt the entire coding structure to accommodate each new observation (Lofland and Lofland 1995). First, I identified commonly occurring elements of each beer package that would be suitable for coding. For example, all beers have a brand name and most have an additional product name that I could compare to other names. I examined each of these elements, in turn, for the meanings they conveyed through words, images, color, shape, or similar means. To do so, I conducted a analysis through inductive content coding (Miles and Huberman 1994). Following Strauss (1990) this included two steps: 'open coding' and 'axial coding.'

'Open coding' involves the unrestricted, tentative assignment of themes to grounded categories (Strauss 1990). I examined each element of each product to determine conceptual categories it might be assigned to. ${ }^{6}$ At first, I identified numerous possible themes and recorded each in a memo (Lofland and Lofland 1995). For example, I originally recorded several possible

\footnotetext{
${ }^{6}$ I referenced websites to clarify information (e.g., the meaning behind a product's name) since many packaging elements reflect content not readily recognizable to non-locals (Schnell and Reese 2003).
} 
themes for the brand name 'Overshores.' The name could invoke 'nautical matters' or 'nature' or simply a 'sense of place.' The goal at this stage of the analysis is not to come up with a unique category for each datum, but to construct generic categories - as few as possible - to which I could assign each of the observations. Thus, when I later examined the 'Ipswich' brand name, I determined that I could more generally categorize both products under 'sense of place,' but that 'nautical' and 'nature' did not fit the new brand. I retained these other two codes as sub-codes of this more generic category. Of course, it is not always possible to subsume all brands under the same code, no matter how generic. The 'Lord Hobo' brand refers to a person, not a place, thus it requires a new code entirely. Conversely, I also assigned products to multiple codes where appropriate. For example, the 'Sam Adams' brand name also refers to a person, but one who is simultaneously and inextricably tied to a place: Boston. I repeated this process for each case, identifying new codes while revising, combining, or deleting older codes. Eventually, I achieved 'saturation' (Strauss 1990), in which I stabilized my coding scheme such that I could summarize additional products with codes I had already developed. Overall, this process attempts to understand what basic themes are present and what they represent.

Next, I commenced 'axial coding' (Strauss 1990), in which I looked at the content of each open code in more depth. Specifically, in this stage of the research I identified how open codes and their sub-codes co-occurred with brewery types via a matrix approach. For example, I plotted how frequently each brewery type made use of elements with a generic code, such as 'place,' or specific sub-codes, like 'nautical' or 'nature.' This allowed me to address my research question of whether there are specific messaging strategies that are characteristic of any particular type of firm. Importantly, this allowed me to examine the content of large and regional 
brewers in particular, given that the literature has placed less emphasis on these firm types and we have little information on what messages they present to consumers.

\section{Findings}

\section{Packaging elements}

Initial overview of the data revealed discreet packaging elements present across most of the observations: brand name, product names, slogans, additional brief statements, longer narrative segments, brand logos, and imagery. 'Brand name' might include a company's name or another name presented as the product line's identity. Some companies have multiple brands, presented as separate and unrelated product lines. For example, Otter Creek Brewing includes three brand identities with distinctive packaging and presentation: Otter Creek, Shed, and Wolaver's. ' 'Product names' might be a simple description of the beer's style (e.g., DuVig's 'Cream Ale') or a more creative product identity (e.g., Foolproof's 'Raincloud'). 'Slogans' are any short statements that serve as a brand's motto. Figure 2 illustrates Long Trail Brewing's motto, "Take a Hike!" Additional 'short statements' that did not serve as slogans (e.g., descriptions of a product's character) were included too. 'Narratives' consisted of occasions when producers dedicated substantial packaging space to text. These were frequently carton bottoms, but also sometimes on carton sides and the back of cans and over-sized bottles. 'Logo' is any text and graphic combination reflecting brand identity. Kent Falls Brewing, as seen in Figure 3, features a stylized image of the eponymous waterfall across their product line. Finally,

\footnotetext{
${ }^{7}$ Wolaver's has been discontinued.
} 
'imagery' refers to all visual elements beyond logos present, including graphics in the foreground and background.

\section{Packaging themes}

I examined each packaging element to determine what message it communicated. I found five broad recurring themes that encompass the overall content of the data: 1) place-based themes, 2) humanization, 3) craft, 4) distinctiveness, and 5) reflexive branding. Importantly, themes were not coded exclusively of each other; one element can reflect several themes, and a brewery can likewise present more than one theme in its packaging.

Place-based themes: Packaging frequently includes elements that associate a product with location or landscape. Brewery names might refer to general regions (e.g., Cape Cod Beer), specific towns (Cambridge Brewing), or natural features (Broad Brook Brewing). They might

refer to ideas associated with place (Grey Sail Brewing near the Rhode Island coast) or historical events (Mayflower Brewing). This also occurs among product names, albeit less frequently (e.g., Boston Lager, Mountain Ale). Slogans could also invoke a sense of locality. Sometimes they only make sense as spatial references. Cisco Brewers' Sankaty Light Lager-a pun referring to a lighthouse — sports the slogan "Don't Fall off the Bluff!" It has no meaning besides drawing attention to the lighthouse on a bluff. Other slogans simply proclaim locality. Thomas Hooker Brewing, named after the Puritan founder of the Colony of Connecticut, simply proclaims itself “Connecticut's Beer.” A profusion of short statements make comparable claims. Most common are statements declaring where a product was made in large print and positioned prominently. Ipswich Ale Brewery makes it easy for consumers to see it is "Brewed in Historic Ipswich, Massachusetts." Frequently, breweries used longer narratives to convey association with place. 
Cottrell Brewing includes a narrative on its carton front: "Ingenuity, Excellence, Character. The essence of the old New England yankee. The elements of Old Yankee Ale [...]. Expertly brewed and bottled by old yankees right here in your neck of the woods. Try it... BE LOCAL, BE AN OLD YANKEE" (capitalization in original). There were many place references among visual elements too. Logos sometimes incorporate direct representations (e.g., the aforementioned Kent Falls in Figure 3) or related activities. Trout River Brewing's logo incorporates a fishing rod and lure. Cape Anne Brewing provided visual representations of local nautical traditions on its cans. Its Fisherman's brand features a man in a raincoat behind the ship's wheel, nautical chart in the background, and compass roses flanking the product name. Going straight to the point, Baxter Brewing, from Maine, includes an image of the state itself on its cans. In total, these methods of referencing landscape and location borrow the identity of places to produce brand identity, suggesting a connection between product and place.

While asserting a connection with place was thus a common theme, the breweries exhibited a number of specific ways of doing so that warrant closer examination. Most of these subthemes are not mutually exclusive—some can co-occur—but, each provides a distinctive portrayal of the character of place.

Pristine nature: Some breweries give a sense of place as an unspoiled wilderness. They portray sweeping landscapes full of natural features, but unmarred by human presence. Keystone Light, Busch Light, and Coors Light (Figure 4) all portray nearly indistinguishable mountain landscapes. Both are shown far off in the distance, white and barren, lacking any sign of life. Great outdoors: This subtheme also emphasizes nature. However, it does so by portraying human activity in the context of experiencing nature. Switchback's logo is just that, a zigzagging trail implying human activity. Long Trail (Figure 2) goes a step further by showing the actual 
hiker and a topographical map. Sebago Brewing features a lake, but there is a boat in the center of it, while Trout River's logo is not the river at all, but a fish on the end of a fishing line and pole.

Nautical: While this subtheme also typically includes boats and water, the emphasis seems to be less on nature and more on the sea as a way of life. Usually, there is also a nostalgic quality present, where that way of life is more historic than contemporary. Harpoon Brewery incorporates its namesake into its logo. As seen in Figure 5, Shipyard Brewing features an oldfashioned ship complete with sales and rigging with a quaint townscape in the background. Thimble Island Brewing includes two tridents, a knotted rope, and even an octopus.

Urban: Very few products feature this subtheme, but it is an interesting counterpoint to the preceding nature-oriented subthemes. Trinity Brewhouse of Providence, RI includes a cityscape across its carton, while the eye of providence hovers overhead, emphasizing the name of the city. Slumbrew is based in Somerville, MA, on the edge of Boston. The city was sometimes called 'Slummerville' on account of its dense population and once sketchy reputation (Annear 2014). Figure 6 portrays their 'Porter Square Porter,' named after an area neighborhood, and features images of a local art installation and a recognizable neighborhood building.

National references: This method involves referring to place on a large scale. It explicitly or implicitly connects the brewery to a nation as a whole without necessarily referencing smaller units of place or specific features. Budweiser famously sports a red, white, and blue color scheme. Yuengling, in Figure 7, likewise seems to assert a connection to the United States in general. Its carton features an eagle flanked by stars and its slogan, “America's Oldest Brewery," suggests how these should be interpreted. 
Regional references: This method is comparable to national references except it changes the scale to encompass a subnational, albeit still relatively large, region. Coors makes several references to the Rocky Mountain region with its images of mountains, discussion of miners, and note that it is "[b]rewed with $100 \%$ Rocky Mountain water." Back East Brewery's name is actually a reference to the entirety of New England, and possibly beyond, since the entire northeast of the country is included in its logo.

State references: Reducing the scale of reference somewhat further, this method identifies a product with an entire state. Foolproof simply includes an image of Rhode Island on its packaging. Trout River is slightly more subtle, stylizing the letter ' $r$ ' in its name into the shape of Vermont.

Local references: Rather than alluding to large areas, like nation or state, this strategy invokes a specific, local place. The scale of place presented here is more intimate and suggestive of real places you can visit. Indeed, many of the places portrayed are likely already familiar to locals and accessible to tourists. Hanging Hills Brewery and Scantic River Brewery are both named after real natural features that you can easily visit, just as Cambridge Brewing and Fort Hill Brewery are named after real, but manmade places. Sometimes locally-scaled references are made to things that are no longer around. The prominent image of a tree on a can of Big Elm refers to a large tree that the people of Sheffield once met under before they had a town hall. Interestingly, the company's website provides the precise location of the tree, even though it is no longer there. ${ }^{8}$

Breweries and maps: Many products feature a painting or photograph of the actual brewery while others include area maps showing the location of the brewery relative to other

\footnotetext{
${ }^{8} \mathrm{http}: / /$ www.bigelmbeer.com/
} 
area locations. Interestingly, these two elements rarely appeared at the same time, suggesting they might share a common purpose and making the inclusion of both redundant. Specifically, these devices both seem to emphasize that the brewery is a real place that you can see and visit, much like local references, but inviting you directly to the establishment itself (cf. Patton and Mathews 2013). For example, Shipyard portrays only a map (Figure 5), while Long Trail (Figure 2) illustrates the more unusual practice of including both a map and an image of their brewery.

Humanization: This theme occurs where products present knowable identities like owners or employees, historical people, or personified mascots. Companies named after owners or founders are commonly occurring examples. Vermont's von Trapp Brewing emphasizes its famous name, the carton notes it is produced "[b]y the family that inspired 'The Sound of Music'." Others are less obvious, like DuVig Brewing. This combines last names of founding families Dugas and Vigliotti, who decided to open a brewery during "the Blizzard of 2013 [when] trapped in their neighborhood with nothing to drink but their own homebrew." 9 Humanizing slogans were rare and generally vague. Stony Creek Brewing exemplifies this: “Simply Great Beer, from Great People, for Great People." While this attempts to establish a bond between producer and consumer, it provides no clear sense of the people behind the brand. Non-slogan statements were more abundant and clearer. A common practice is simply writing the owner's name on packaging, often with a simple salutation. Rock Art Brewing states "To you and your friends! Enjoy! Matt and Renee.” This provides a sense of communication, like a quasipersonal letter to consumers. One compelling humanizing technique involves touching tributes to lost loved ones. Only three products included such tributes. Scantic River Brewery states, on its 'After Midnight' porter, "In memory of Kenneth Koontz and his prized truck named 'After

\footnotetext{
${ }^{9}$ http://www.duvig.com/our-story/
} 
Midnight'." Longer narratives are useful for humanization too. Spencer Brewery is operated by the only certified Trappist monks in America as their packaging makes clear. Within their lengthy cartons narratives, we learn about the monks, the abbey, their charity, and their mission to "follow the Benedictine counsel of ora et labora (pray and work)". We learn from the narrative on the bottom of a Jack's Abby carton, that the brewery is owned by three brothers and named after one of their wives (Figure 8). Logos and images include a range of personalities. Some are real people, like Kurt Vonnegut who appears on Cape Cod Brewing's 'Kurt's Farmhouse.' A Slumbrew carton includes a photo of the owners along with a handwritten greeting and signature (Figure 6). Black Hog Brewing illustrates how imagery can instead be generic or cryptic. A can of their Granola Brown Ale features an anonymous but quirky hiker whereas the black hog in question refers to the owners' family cookouts - a topic discussed at such length on the company website that one can almost smell the barbecue. ${ }^{10}$ Not all humanizing themes are strictly human. Some graphics feature likeable mascots instead (Hede and Watne 2013). Sea Dog Brewing is personified by a friendly-looking dog in a rain hat whereas Baxter Brewing sports an anthropomorphic, winged moose. Overall, humanizing themes make inanimate products more personal and knowable, whether by referring to real people or branding a likeable personality.

Craft: This theme occurs where packaging invokes elements associated with craft brewing: small scale, attention to detail, tradition, and intensive descriptions of beer content or character (Brewers Association 2016d). While no brand name clearly indicated 'craft' on its own, some product names suggested it by indicating traditional recipes (e.g., Yuengling Traditional Ale, Ipswich Original Ale) or unusual styles (e.g., Hanging Hills' Yellow Pale Ale,

\footnotetext{
${ }^{10} \mathrm{http}: / /$ blackhogbrewing.com/about/
} 
Overshores' Belle Fermiére). Only one logo was indicative of craft (Spencer Brewing's 'Authentic Trappist' product seal), while some indicated or heavily suggested it. Opa-Opa Brewing proclaims it is "handcrafted" while Two Roads Brewing subtly thanks "you for taking the road less travelled," simultaneously invoking the Robert Frost poem from which its name is derived as well as the relatively small-scale character of their product. 'Statements' were more common carriers of craft characteristics. Like slogans, these often simply proclaimed craft character, such as being "Handcrafted in Vermont" (Otter Creek), but might also invoke specific characteristics. Newport Storm states that its products are "Brewed in small batches so every drop counts." Narratives were the most common means of communicating craft, perhaps because these provide sufficient space. Jack's Abby Brewing discusses traditional methods, lengthy brew process, and detail on ingredients and product characteristics (Figure 8). Craft messaging communicates that products are not quickly and thoughtlessly mass-produced, but rather lovingly crafted with great effort and thoughtful attention.

Distinctiveness: This theme was coded when a brand's identity did not readily fit the more standard appeals to place, humanization, or craft, but when a strong theme was nonetheless present. 'Funky Bow', for instance, has a musical theme. Beyond brand name, this is evident in the product name (G-String, with additional sexual connotations), narrative (which discusses music), and imagery (banjo and bow). Magic Hat Brewing presents a nonspecific theme on its \#9 product, invoking magic and mystery as seen in Figure 9. In addition to brand name, its logo is a moon and starburst reminiscent of stage magician symbols, a vague statement about the product being hard to describe, misty swirl patterns across the packaging, and a narrative suggesting the beer's names is mysterious. Why is it called \#9? As prior work has found, ethnic themes can distinguish brands too (Mathews and Patton 2016). Old Burnside Brewing exhibits a Scottish 
theme with its logo (a Scottish claymore sword), imagery (thistle), and narrative (which discusses the Scottish "twist" in their recipes). Like all distinctive themes, these serve to distinguish the brand, but European themes of this sort can imply several things. They are not strictly place-based unless there is a local connection. This brewery is located in the "Burnside section of East Hartford" while "'Burn' is a Scottish word for brook or stream". ${ }^{11}$ Thus, there is a place-based neighborhood theme as well as a more exotic, distinctive theme drawing on foreign traditions. Distinctive themes provide a brand's identity by referencing familiar concepts: music, mystery, European culture, and so forth. They give brands unique personality by distinguishing them from others, proving an identity that stands out from the landscape of competitors. Indeed, distinctive identity is so important that lawsuits defending it are not uncommon. Magic Hat, for example, sued Kentucky-based West Sixth brewing for using designs "that closely resemble and are confusingly similar" to their own (Spears 2013).

Reflexive Branding: I use the term 'reflexive branding' to describe branding themes that do not establish identity by borrowing from external, preexisting systems of meaning (e.g., established places or common themes like music), but rather simply refer to themselves. They repeat the brand's identity — its name, symbols, or distinctive colors — without actually providing specific meanings. First, some brands that use this theme have names with no obvious external referent. Keystone brand, for example, refers to a general concept rather than anything specific, and its meaning for the brand is unspecified. Likewise, 'Bud' has no inherent meaning. Although it is a truncated form of an old family name, the brand shies away from this rather than acknowledging it. Product names are more revealing. Many reflexively branded products do not have a separate name for their beers distinct from the brand name. Thus, a Heineken is a

\footnotetext{
${ }^{11} \mathrm{http}: / /$ oldeburnsidebrewing.com/burnside-ice/
} 
Heineken and a Budweiser is a Budweiser. When a line of products with the same brand name exists, they receive only slight modifiers to distinguish them rather than distinct identifiers. For instance, Heineken Light simply adds a word to the brand name rather than receiving an entirely new name. Compare this practice to that of Down the Road Beer Company, which does not use reflexive branding. Referencing a legendary villain from British folklore, their London Porterstyle beer is called 'Spring Heel Jack.' This product, like all their products, has a clear identity distinct from the brand itself. Reflexive branding is equally evident in logos, which tend to provide no information on their own, but simply refer to the brand. Bud Light's logo is an abstract crescent shape that partly circumscribes the brand name in its familiar typeface. Compare Smuttynose Brewing's logo: a harbor seal in front of a rocky shoal, which communicates a sense of place and not just brand. Likewise, Powder Hollow's logo consists of two crossed muskets. Slogans are similarly self-referential. Coors Light is, for some reason, "The Silver Bullet" (Figure 4) while Budweiser is "The King of Beers." Reflexively branded products tend not to use statements or narratives — perhaps because they distract from a simple messagebut some do appear. Bud Light simply states that it is "America's Favorite Beer" while Icehouse's narrative largely repeats its slogan several times: "Ice Brewed Below Freezing." Imagery on reflexive products is particularly interesting because of its variance from all other themes and, again, a lack of semantic distinction. In general, these packages tend toward blandness, with many fewer visual elements present than those of other themes. Those images that are present, predictably, tend toward meaninglessness or self-reference. Most common and revealing of these is the use of 'bottle replication': the practice of including images of beer bottles or cans on cartons, even if that carton is an open six-pack where the actual bottle is visible. Finally, one visual element involved actually modifying standard packaging to create a 
sort of gimmick. Miller Lite offers a bottle with a twisted neck that it breathlessly promotes as a 'vortex' bottle, Keystone light excitedly offers its 'widemouth' can with enlarged opening for drinking, and Bud Light Lime has its "New bottle with a twist." This is an asymmetrically shaped vessel that reflects their slogan, "Refreshment with a twist." With no external meaning and questionable function, gimmicks draw attention and underline brand identity more than anything else. By referring only to themselves instead of other known symbols, reflexive brands rely on pre-existing consumer symbolic systems or, perhaps, on other means of communicating meanings not present on packaging. Even lacking these referents, the cultural pervasiveness of macro-brands as familiar symbols might preempt the need to refer to anything specific beyond the brand itself.

\section{Firm types and use of themes}

Each packaging element was coded dichotomously for whether each theme was present (cf. Holtkamp et al. 2016). By summing the number of elements within the packaging of each product that communicated each theme (e.g., brand name, product name, etc.) scores were calculated that provide estimates for how prevalent each theme was per product. This rating could vary from $0-7$, where 0 represents absence of a given theme whereas 7 indicates considerable theme presence. For example, if a product contained three elements that tied it to a place and none to particular people, it would receive a score of 3 for 'place-based' and 0 for 'humanized.' Table 1 presents average scores and standard deviations for each theme by brewery type to compare relative occurrence. Three themes map closely onto neolocal concerns: emphasis on real locations, real people, and non-mass-produced beer (place-based, humanization, and craft themes, respectively). Distinctiveness also likely reflects neolocalism 
since it communicates something unique (Holtkamp et al. 2016), 'authentic' (Schnell 2011), and different from a mass-produced, homogenized product (Schnell and Reese 2003). Conversely, reflexive branding does not reflect the ideals of neolocalism. We would expect neolocallyoriented firms to make greater use of all themes except reflexivity.

Large breweries: As shown in Table 1, the largest firms used the fewest place appeals, about 1.55 per carton on average. As indicated by the standard deviation (1.56), many did not use this technique at all. However, a considerable number did, and rivaled smaller breweries in this regard. Nonetheless, closer analysis suggests any similarity in strategies is superficial. When large brands used place, they most commonly appealed to 'pristine nature' and this is almost always in the form of mountainous landscapes. Coors Light claims to be "as cold as the Rockies" and its carton, in Figure 4, portrays generic looking mountains that could be anywhere. Interestingly, even its recycled materials logo is stylized into the outline of a mountain. It claims a 'Rocky Mountain Heritage,' but fails to specify anything further. A similar, vague treatment of place is evident in large breweries' characteristic use of 'national references.' Modelo Especial notes it is 'imported from Mexico' repeatedly, presents a small amount of Spanish, and its brand logo could be construed as 'Mexican' in appearance, but like Coors does not mention anything more nuanced. Thus, when large brands deal with places at all, they treat them as broad and diffuse, not as specific locations with their own history, identity, and culture — as if all of the Rockies or all of Mexico were homogenous. This is consistent with O'Neill et al.'s (2014) suggestion that place imagery, if sufficiently broad (i.e. national), might be useful to large breweries in their efforts to appeal to broad customer bases.

To examine this possibility further, we can look more closely at the varying scales brewers use to represent place. Table 2 divides the place-based themes into further categories 
based on the scale subthemes described above (i.e. national, regional, state, and local) and lends further evidence to this pattern. Of the four scales coded, large breweries make the greatest use of the largest ones: national and regional references $(0.59$ and 0.55 occurrences per observation on average). They use no state-oriented references. At first glance, their local references appear to fall not too far behind regional references. However, there is considerable variation in the number of uses as indicated by the standard deviation (0.96). In fact, the average (0.45) is skewed by the presence of a single case (i.e. Icehouse) and drops considerably when that case is dropped (0.29). The majority of the remaining local references are prominent statements claiming association with a particular city, such as Keystone Light's association with Golden, Colorado.

To the extent that large firms appeal to place, they actually did so more than they appealed to humanization, craft, or distinctiveness. These themes occurred so rarely that further analysis of them among large breweries was not informative. What is revealing, however, is one theme in which these firms dominate: reflexive branding. More than other firms, large breweries used marketing techniques that reinforced and referred back to the brand itself. Interestingly, these include little information for interpreting that brand. There are few references to familiar qualities like places or people. This could maximize flexibility to appeal to widespread and diverse customer demographics. Without obvious, fixed meanings, these brands can promote variations on their identities in different times and locations without having to vary packaging. For this, they likely rely on other marketing mechanisms, like television, to reach specific audiences. The current data do not allow an examination of this possibility. However, it is consistent with two observations: 1) that large firms devote substantial budgets to advertising which smaller firms cannot afford (Clemons et al. 2006) and 2) little differentiation exists across 
the products of large breweries, but there is considerable variation across their marketing campaigns (Eberts 2014).

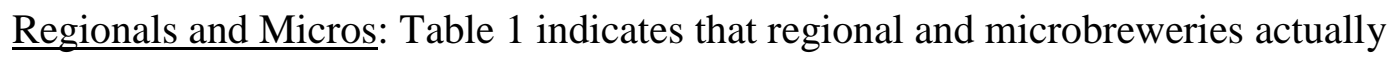
contained fairly similar content in their packaging overall. On average, both types used nearly every theme more frequently than large breweries. The sole exception is reflexive branding, which both used sparingly. While this similarity between regionals and micros is itself surprising, additional comparison reveals further similarities and differences that are informative.

First, both regionals and micros use place themes more frequently than any other theme. Unlike large brewers' use of place, both portray place more intimately and on a smaller scale. Many favor a 'great outdoors' theme with human activity central to the experience of nature. Hiking, boating, fishing, and so on are emphasized over barren landscapes. Indeed, mountains themselves are rarely referenced and even when they are, they are shown as inhabited. Berkshire Brewing featured one of the only mountains to appear on a label outside of the large breweries. Instead of an anonymous, bleak landscape on its Mount Greylock Porter, we are treated to a close-up view of the mountain's War Memorial Tower and can barely see the mountain itself. In terms of scale, not surprisingly, both regionals and micros eschew the national level as well. For example, Table 2 indicates that microbreweries make only 0.04 references to the nation on average compared to large breweries at 0.59 . Instead, references to places become more frequent for regionals and micros as scale decreases. Thus, they refer to New England more commonly than the nation, to specific states more than New England, and to specific towns or landmarks more than states.

Delving further, there are some differences to consider. Interestingly, regionals actually make greater use of overall place-based themes than micros: 3.69 elements per package on 
average compared to 2.88 , respectively (Table 1 ). In comparing scale, this difference is most evident at the local scale, where regional breweries have a sizeable lead over microbreweries, making 2.50 references per product on average versus 2.10 (Table 2). At every other scale, they are nearly identical. Possibly, regionals' larger size and wider distribution makes it more important for them to assert a local character through marketing, whereas microbreweries are more self-evidently local. Conversely, it is possible that a more effective use of place-based marketing enables some breweries to expand to the regional size over less effective competitors. The elements used to communicate place vary somewhat as well. The three most commonly used elements communicating place among the regionals were visual imagery other than logos (with $88 \%$ of regional products including these), brand name (75\%), and statements other than slogans (69\%). For microbreweries, these same elements were also the most commonly used, but the order of priority was reversed: statements $(65 \%)$, brand names $(55 \%)$, and imagery (51\%). Their actual representations of place are more similar to each other than they are to that of large breweries, but some divergence is apparent. Few breweries make use of modern, urban, or industrial imagery, but nearly all of these are microbreweries. The sole exception is the regional, Two Roads.

While humanized, craft, and distinctive themes were very similar across regionals and microbreweries. These firm types also differ in terms of reflexive branding. While both lag behind large brewers in its use, regionals use it nearly twice as much as micros. This most frequently occurred among product names, which were sometimes not distinct from the brand itself, much like larger breweries. 'Long Trail Ale' is that brand's flagship product, with only the term 'Ale' distinguishing it from the brand (Figure 2). This is qualitatively similar to rarely occurring reflexivity among the micros but, as this example illustrates, the sort of reflexivity 
encountered among regionals is less pronounced than the large breweries. This might reflect an attempt to increase market size while simultaneously retaining a place-based association.

\section{Discussion and conclusion}

All branding themes, including those discussed above, try to establish connections between products and consumer (Aaker 1997). However, as predicted, specific strategies may not be equally suitable to every kind of firm. This paper contributes to our understanding of these patterns among breweries.

First, the findings support previous work arguing that beer packaging contains elements that directly appeal to neolocally-motivated consumers in the form of place, human connection, craft, or distinctiveness. Additionally, I found support for the previously untested, but reasonable assumption that large brewers make the fewest appeals to neolocalism, opting instead to appeal to a broader demographic through reflexive branding. Interestingly, the neolocal characteristic they most frequently reference is 'place' — not humanization, craft, or distinctiveness. However, when they do, they treat place as a broad and homogenous concept, not as something local and specific. This is particularly noteworthy considering it might actually be easier for them to express these other themes. Most large breweries, for example, are named after real founding families, but few seem to leverage the fact. There are a number of possible reasons for this. Perhaps these real people lived too far in the past to be relevant and their descendants are less frequently involved in the breweries. Perhaps the names of such individuals have a negative connotation (i.e. Adolph Coors, Adolphus Busch). Or perhaps any specific ties to place or history make it harder for these brands to appeal to broad, diverse demographics. Despite the occasional references to place, large firms most frequently made use of reflexive branding. The hallmark of 
these brands, then, is not their failure to reference place, per se, but their propensity to reference themselves as self-contained semantic wholes.

There are of course exceptions beyond the scope of the current paper. Anheuser-Busch InBev famously bought Chicago's Goose Island Brewery in 2011 but this is not readily apparent when perusing the brewery's website or even a bottle of their beer. Getting into local markets by buying local brands or producing faux-local brands is part of the market strategy of these large firms. Prior to its 2016 merge with SAB Miller, AB InBev described itself as being in the "business of building high quality brands."12 This included a focus on three categories: 1) "Global brands... built on values and experiences which appeal to consumers across borders" (e.g., Budweiser, Beck’s), 2) “Multi-Country brands” which “connect with consumers across continents" (e.g., Hoegarden, Leffe), and 3) "Local Champions" that "[c]apture the local needs of our consumers." The latter included dozens of brands worldwide, each claiming some local connection, such as Chernigivske, "the brand of the Ukrainian national pride, preferred by consumers as a 'True Ukrainian Quality' beer." Following the merger, the company now holds over 400 brands worldwide and likely follows a similar strategy. A comparison of these quasilocal beers to those produced by craft microbeers could offer compelling insights.

What distinguishes both regional and microbreweries from large firms is that they primarily borrow meanings from elsewhere. They reference something, anything, and incorporate it into their own brand identity. Surprisingly, the findings also suggest that regional breweries - largely ignored in the literature — are actually the most likely to borrow meanings in this way, especially in terms of their use of place-based elements on a local scale. If anything, the literature would lead us to expect they would be surpassed by the microbreweries in this regard,

\footnotetext{
${ }^{12}$ http://www.ab-inbev.com/go/brands/brand_strategy.cfm.
} 
given the latter's smaller size and integration into specific communities. This begs two questions. First, are place appeals really prerequisite for the success of small breweries if such appeals are actually more commonly used by larger, regional firms? Second, do place appeals really limit a brand's customer base to people who live reasonably close by (Eberts 2014)? The limit might be much greater than previously imagined. Sam Adams brand is beginning to appear among national best-sellers despite its specifically Bostonian identity (Statista 2017). Indeed, many of its beers are now brewed in places like Breinigsville, Pennsylvania and Cincinnati, Ohio. ${ }^{13}$ but its appeal as a brewery rooted in a real place seems to have remained intact. It is possible that products are considered authentically local and worth supporting as long as they come from somewhere known and specific — even if that place is not necessarily nearby (Schnell 2013).

Simultaneously, regional breweries flirt with reflexive branding, and the concurrence of this with more specific references akin to the micros raises interesting questions. Most regionals started out as microbreweries and may have maintained original brand identities established during that time. An interesting counter-example is Two Roads Brewing, in Stratford, CT, which actually started off as regional (Siss 2015), but which made only one place reference in the analysis. These findings support Carroll and Swaminathan's (2000) observation that regional firms are awkwardly situated between two opposing business models. They must appeal to a local market, but seek a broader one. Perhaps increased place appeal is a result, not a cause, of growth. In search of expansion, they may embrace some of the tools of their largest competitors, in the form of reflexive branding, while reinvigorating claims to local authenticity by using more place appeals. Microbrewers, conversely, may not need to assert their locality so vigorously, on

\footnotetext{
${ }^{13}$ See http://www.mcall.com/business/outlook/mc-outlook-samuel-adams-20150314-story.html and http://www.hoperatives.com/the-boston-cincinnati-connection/.
} 
account of being more explicitly rooted in specific places within identifiable communities, and have little to gain from reflexive practices.

Despite these possibilities, comparison of neolocalism between small and regional firms warrants further investigation. Future research could test which of the findings in the current study hold with larger, random samples. Given the decision to emphasize quality of data over quantity by examining entire beer packages, many potential cases were omitted from the sample. This could be addressed by narrowing the focus to a single state, especially one like New Hampshire that was not well-represented in the data (see Figure 1). Conversely, research could be directed at comparing data drawn from packaging to online data to determine if there are really differences across these methods.

Of course, there are many opportunities to expand the scope of research too. Indeed, additional research should be directed at regional-sized breweries in particular. These are still poorly understood given their relative absence from the literature. It is possible that the patterns reported here do not hold in other regions beyond New England. Likewise, other firm types, such as brewpubs and contract breweries - have similarly received little attention. Moreover, imports have long been competitors for the same customers as domestic beers, but no systematic work examines their appeal. Finally, methods beyond content analysis have been underutilized in regard to understanding how packaging and other marketing devices affect consumer perceptions of microbeers. While informative, content analysis does not tell us how consumers actually perceive packaging or the role it plays in their purchasing choices. Fletchall's (2016) work includes interviews with microbrewery visitors and demonstrates the utility of other approaches. In short, there are ample opportunities for future research. Inquiries of this sort are important, and not only because they can improve our understanding of the beer market. The 
landscape and culture of beer is contested and continually shifting precisely because it is inexorably linked to so many other important and contentious phenomena. When a consumer purchases a particular beer, they are doing more than just buying a product. They may be establishing a connection to a place or to their neighbors, constructing a sense of identity, or perhaps even trying to promote social change in the face of globalization. Understanding the beer market can help us gain significant insights into these other social and cultural processes that guide and shape that market.

\section{References}

Aaker, J.L. 1997., Dimensions of brand personality. Journal of Marketing Research, 34(3):34756.

Adams, B., 2014. Old and new New Englanders: Immigration and regional identity in the Gilded Age. Ann Arbor, MI: University of Michigan Press.

Alcohol and Tobacco Tax and Trade Bureau. 2018., Beer Statistics. Available at:

https://www.ttb.gov/beer/beer-stats.shtml. [Accessed April 2, 2018].

Annear, S., 2014. From 'Slummerville' to Somerville. Boston Magazine. Available at www.bostonmagazine.com/news/2014/11/25/somerville-video-harvard-kennedy-school. Accessed November 3, 2017.

Baginski, J. and Bell, T.L., 2011. Untapped? An analysis of craft brewing in the Southern United States. Southeastern Geographer, 51(1): 165-85.

Bowden, M., 1992a. Invention of American tradition. Journal of Historical Geography, 26(2): 187-194.

----. 1992b., Invented tradition and academic convention in geographical thought about New England." GeoJournal, 26(2): 187-94.

Brewers Association. 2013., Craft brewing statistics. Available at: www.brewersassociation.org/pages/bussiness-tools/craft-brewing-statistics/facts. [Accessed August 3, 2013]. 
Brewers Association. 2016a., Number of breweries. Available at:

https://www.brewersassociation.org/statistics/number-of-breweries/. [Accessed December 14, 2016].

Brewers Association. 2016c., Craft beer industry market segments. Available at https://www.brewersassociation.org/statistics/market-segments/. [Accessed November 3, 2016].

Brewers Association. 2016d., Craft brewer defined.

https://www.brewersassociation.org/statistics/craft-brewer-defined. [Accessed January 4, 2017].

Brewers Association. 2018., National beer sales and production data.

https://www.brewersassociation.org/statistics/national-beer-sales-production-data/. [Accessed June 1, 2018].

Carroll, G.R. and Swaminathan, A., 2000. Why the microbrewery movement? Organizational dynamics of resource partitioning in the U.S. brewing industry. American

Journal of Sociology, 106(3):715-62.

Clemons, E.K., Guodong, G., and Hitt, L.M., 2006. When online reviews meet hyperdifferentiation: A study of the craft beer industry. Journal of Management Information Systems, 23(2):149-71.

Conforti, J.A., 2001. Imagining New England: Explorations of regional identity from the pilgrims to the mid-twentieth century. Chapel Hill, NC: University of North Carolina Press.

DBJ Staff., 2013. Top 20 selling beers of 2012. Dayton Business Journal, (January 11). Available at www.bizjournals.com/dayton/news/2013/01/11/top-20-selling-beers-of-2012.html. [Accessed February 14, 2013].

Debies-Carl, J.S., Punk rock and the politics of place: Building a better tomorrow. New York: Routlege.

Demeter Group. 2013. State of the craft beer industry. Available at [www.demetergroup.net/docs/persepectives/Craft_Beer.pdf]. Accessed August 3, 2013

Eberts, D. 2014., Neolocalism and the branding and marketing of place by Canadian microbreweries. In M. Patterson and N. Hoalst-Pullen, eds. The geography of beer: Environments, Regions, and Societies. New York: Springer Verlag, 189-99.

Flack, W. 1997., American microbreweries and neolocalism: 'Ale-ing' for a sense of place. Journal of Cultural Geography, 16(2):37-53.

Fletchall, A.M. 2016., Place-making through beer-drinking: Case studies of Montana's craft breweries. Geographical Review, 106(4): 539-66. 
Feintuch, B. and Watters, D.H., eds., 2005. Encyclopedia of New England. New Haven, CT: Yale.

Hede, A. and Watne, T. 2013., Leveraging the human side of the brand using a sense of place: Case studies of craft breweries. Journal of Marketing Management, 29(1-2):207-24.

Holtkamp, C., et al., 2016. Assessing neolocalism in microbreweries. Papers in Applied Geography, 2(1):66-78.

Klein, N., 1999. No Logo: Taking aim at the brand bullies. New York: Picador.

Koontz, A., 2010. Constructing authenticity: A review of trends and influences in the process of authentication in consumption. Sociology Compass, 4(11): 977-88.

Lofland, J. and Lofland, L.H., 1995. Analyzing social settings: A guide to qualitative observation and analysis. New York: Wadsworth.

Mathews, A.J. and Patton, M.T., 2016. Exploring place marketing by American microbreweries: Neolocal expressions of ethnicity and race. Journal of Cultural Geography, 33(3): 275-309.

Miles, M.B. and Huberman, A.M., 1994. Qualitative data analysis. Thousand Oaks, CA: Sage.

Miller, N., 2012. Beer lover's New England. Globe Pequot: Guilford, CT.

Murray, A. and Kline, C., 2015. Rural tourism and the craft beer experience: Factors influencing brand loyalty in rural North Carolina, USA. Journal of Sustainable Tourism, 23 (8/9): 11981216.

Murray, D.W. and O’Neill, M.A., 2012. Craft beer: Penetrating a niche market. British Food Journal, 114(7): 899-909.

Ogle, M., 2006. Ambitious brew: The story of American beer. New York: Harcourt.

O’Neill, C., Houtman, D., and Aupers, S., 2014. Advertising real beer: Authenticity claims beyond truth and falsity. European Journal of Cultural Studies, 17(5):585-601.

Patton, M.T. and Mathews, A.J., 2013. Marketing American microbrews: Promoting neolocalism one map at a time. Papers in Applied Geography, 36: 17-26.

Porter, M.E., 1980. Competitive strategy. New York: Free Press.

Schnell, S.M., 2013., Deliberate identities: Becoming local in America in a global age. Journal of Cultural Geography, 30(1):55-89.

-----. 2011., The local traveler: Farming, food, and place in state and provincial tourism guides, 1993 - 2008. Journal of Cultural Geography, 28(2):281-309. 
Schnell, S.M. and Reese, J.F., 2003. Microbreweries as tools of local identity. Journal of Cultural Geography, 21(1):45-69.

Shepherd, S., Chartrand, T.L., and Fitzsimons, GJ., 2015. When brands reflect our ideal world: The values and brand preferences of consumers who support versus reject society's dominant ideology. Journal of Consumer Research, 42(1): 76-92.

Shortridge, J.R., 1996. Keeping tabs on Kansas: Reflections on regionally based field study. Journal of Cultural Geography, 16(1):5-16.

Siss, W., 2015. Connecticut beer: A history of Nutmeg State brewing. Charleston, NC: History Press.

Smith, G., 1998. Beer in America: The early years, 1587 - 1840: Beer's role in the settling of America and the birth of a nation. Boulder, CO: Siris.

Spears, V.H., 2013. Brewer Magic Hat files federal lawsuit against West Sixth Brewing. Lexington Herald Leader. Available at http://www.kentucky.com/news/local/crime/article44425182.html. [Accessed December 12, 2017].

Statista. 2017., Beer industry. Available at https://www.statista.com/study/9893/beer-industrystatista-dossier/. [Accessed March 3, 2017].

Strauss, A.L., 1990. Qualitative analysis for social scientists. New York: Cambridge.

Terozono, E., 2018. US craft beer slowdown sends hops market from boom to bust. Financial Times. Available at https://www.ft.com/content/0f678bd6-0cc7-11e8-839d-41ca06376bf2. [Accessed March 30, 2018]

Wood, J.S., 1997. The New England village. Baltimore: Johns Hopkins University Press.

Yenne, B., 2003. The American brewery: From colonial evolution to microbrew revolution. Saint Paul, MN: MBI.

Zaltman, G., 2003. How customers think: Essential insights into the mind of the market. Boston: Harvard Business School Press.

\section{Captions for Tables and Figures}




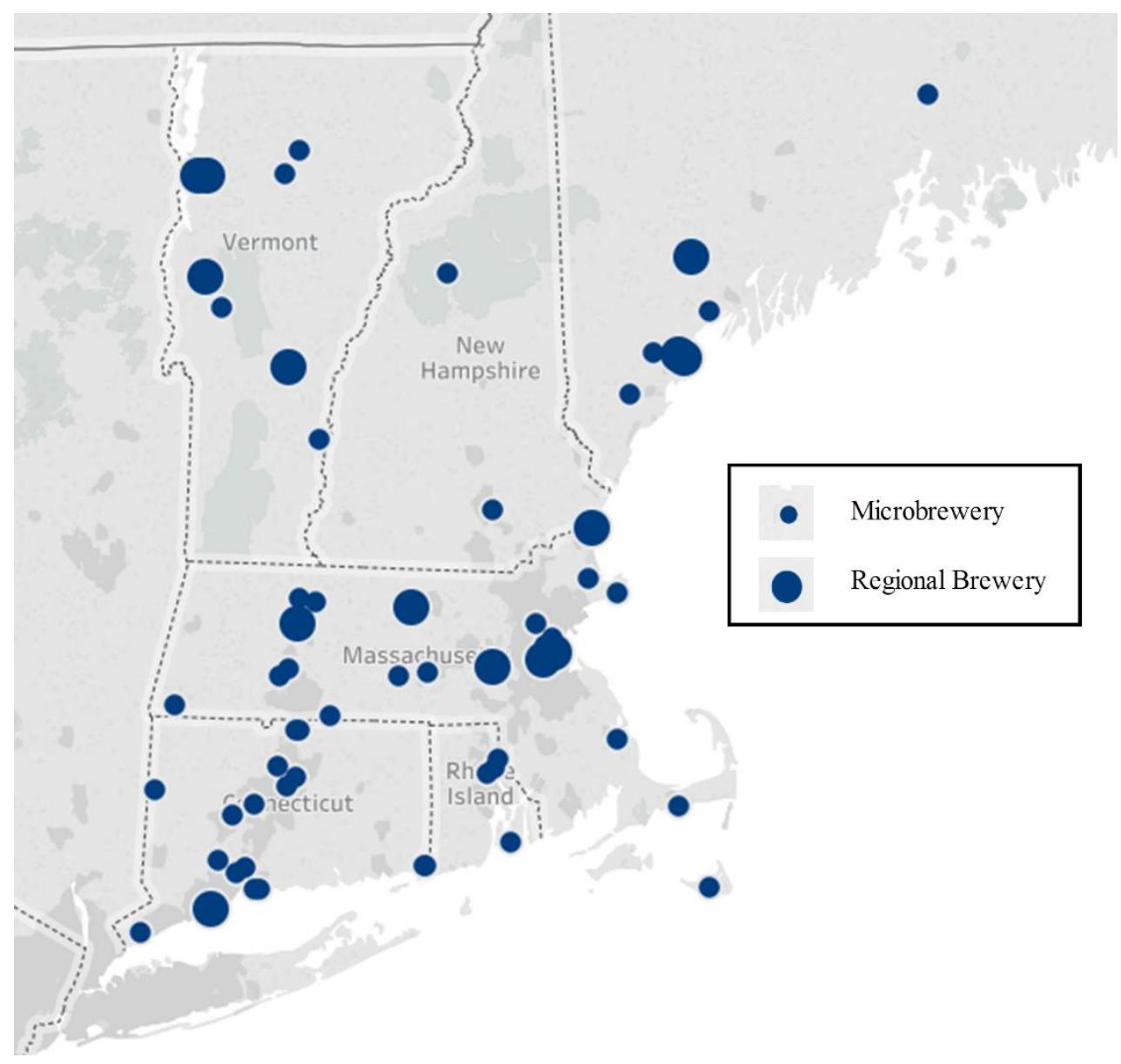

Figure 1. Locations of Micro- and Regional Breweries in Sample

- The locations of New England microbreweries and regional breweries in the sample. Breweries are well-represented within the more heavily populated southern and coastal districts. No large brewery is headquartered in the region. 


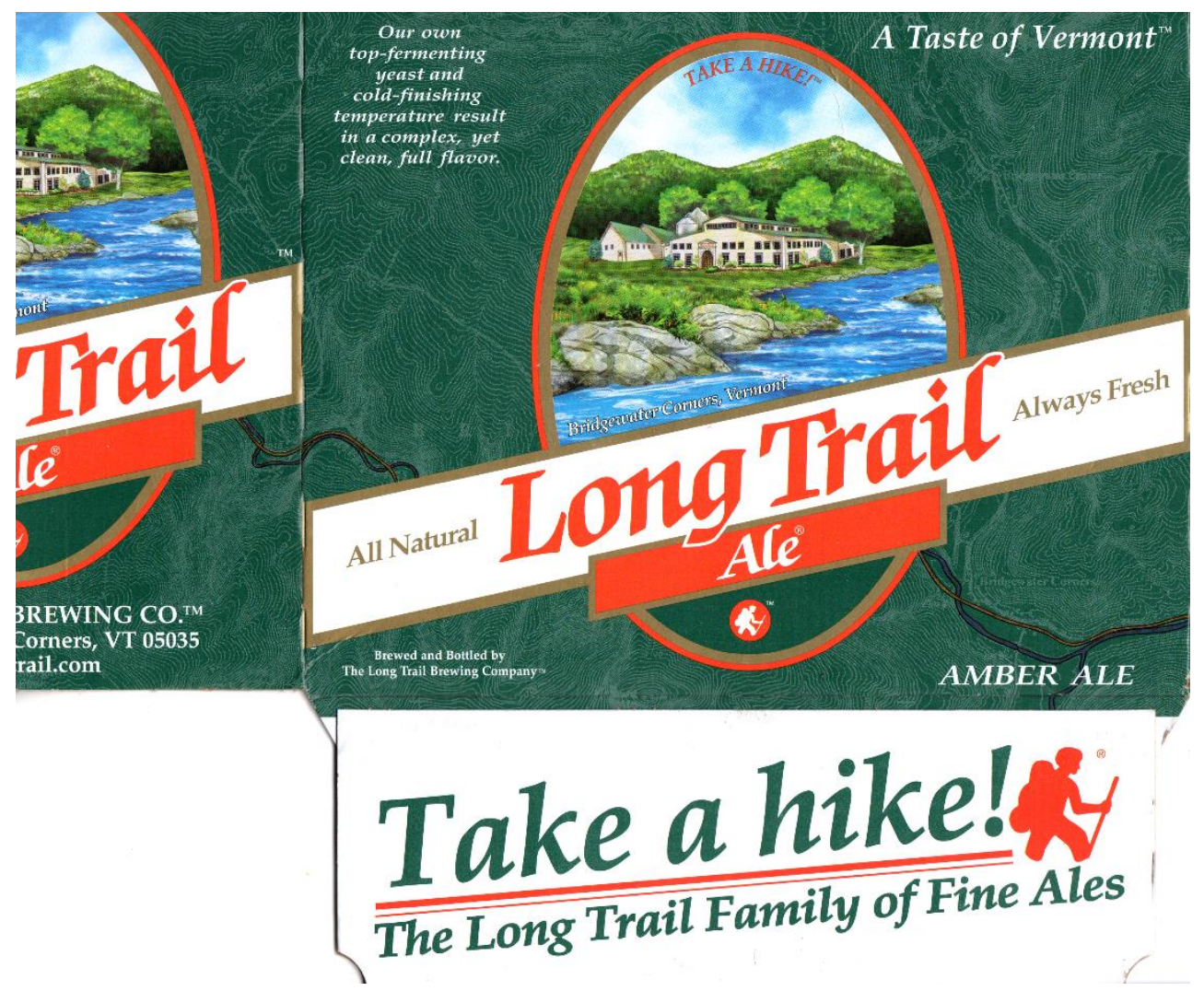

Figure 2. Long Trail Ale

- More than just a beer, this regional brewery offers an experience of place with its name (taken from a famous Vermont trail), various texts ("Take a Hike!"; "A Taste of Vermont"; "Bridgewater Corners, Vermont"), and imagery (the brewery in its scenic milieu, hiker logo, and topographic map background). 


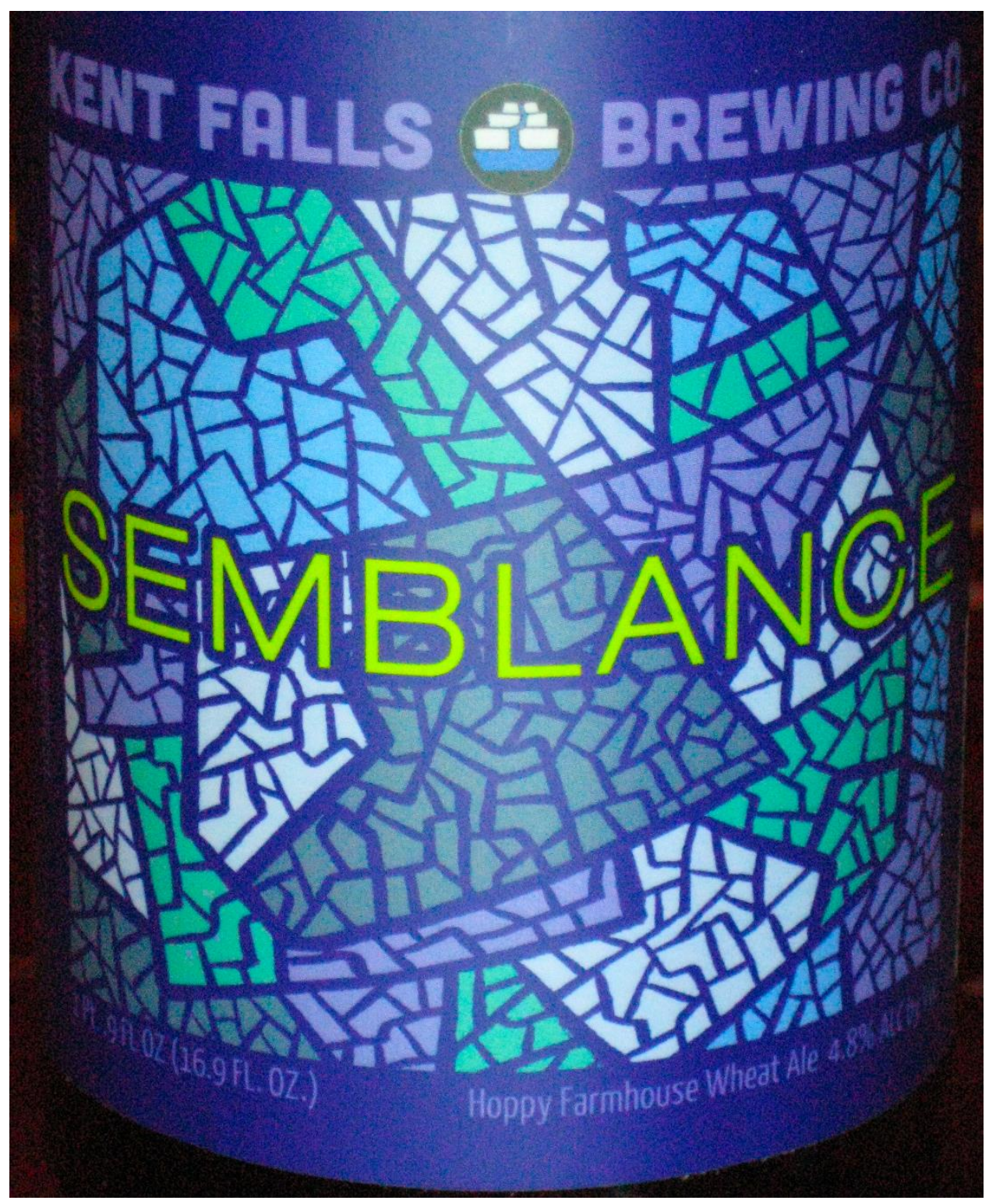

Figure 3. Kent Falls Semblance

- A rich, but fairly subtle representation of place, this microbrewery is named after the local waterfall in Kent, Connecticut, which is also stylized in its logo. Yet, the primary image is an abstract, artistic design that catches the viewer's attention and makes the label distinctive. 


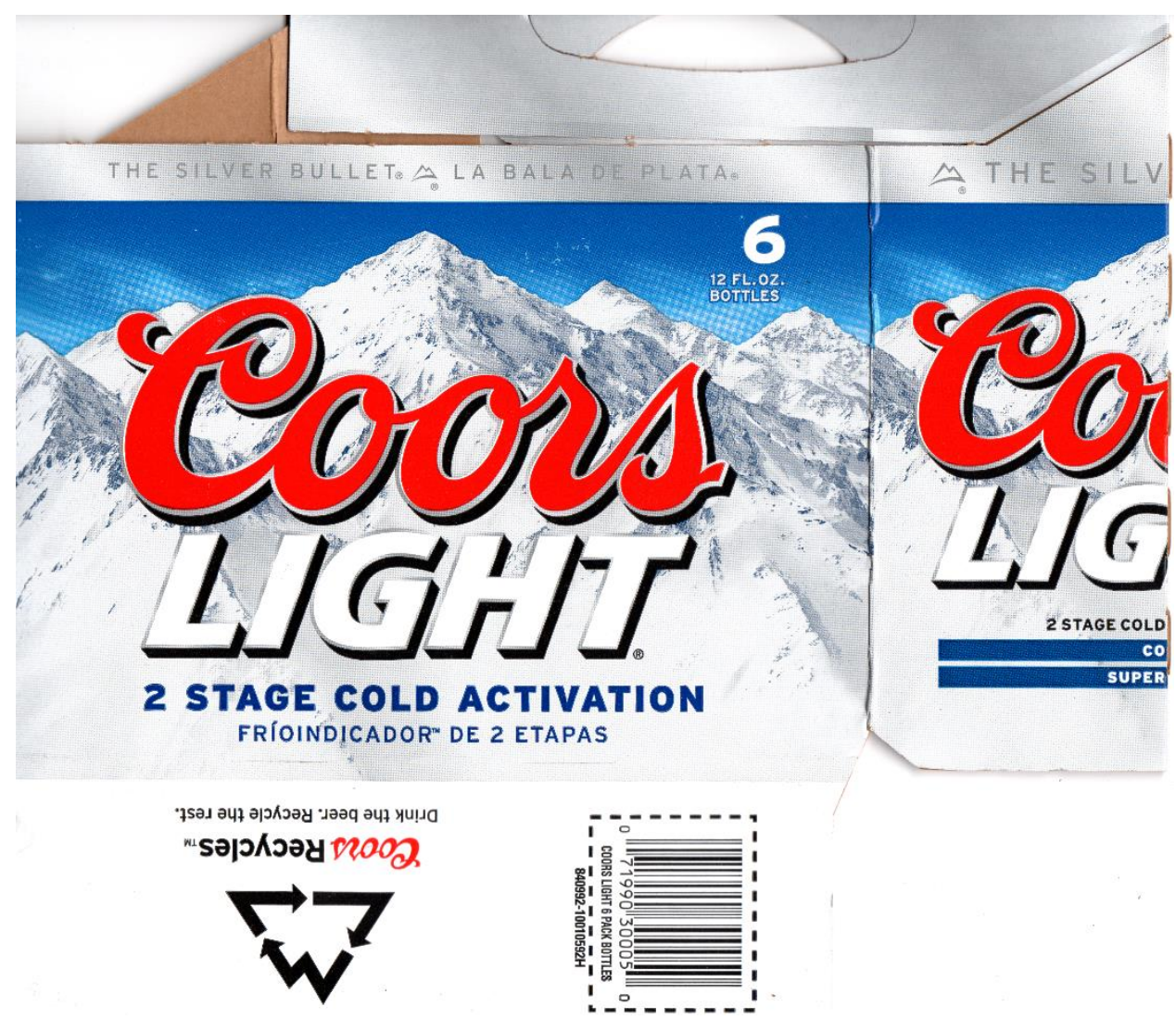

Figure 4. Coors Light

- Place as vast landscape full of natural features, but no signs of life and no indication of its specific location. Its slogan, "The Silver Bullet," provides no real information, but reflexively reinforces the brand identity of this large brewery's product. 


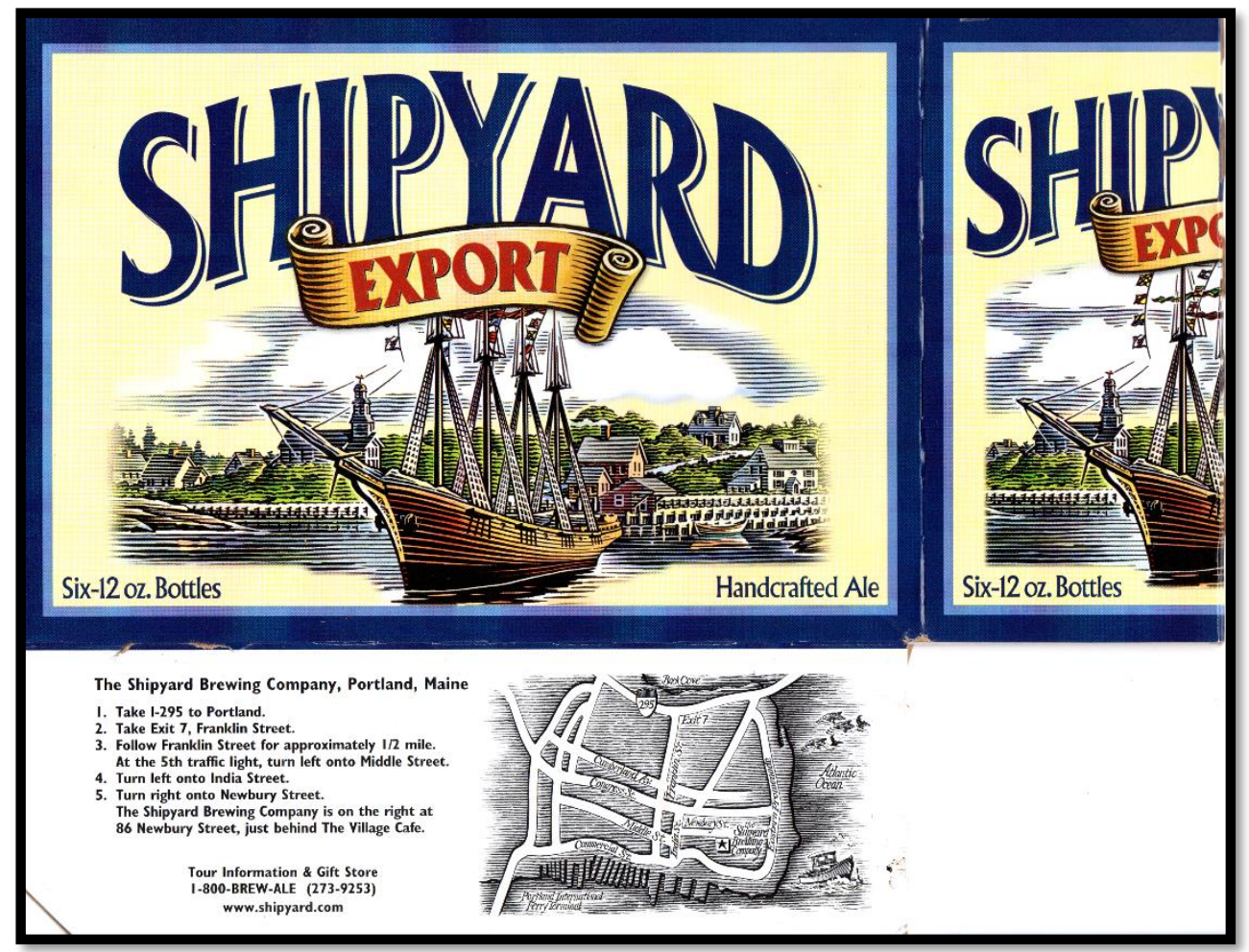

(detail)

The Shipyard Brewing Company, Portland, Maine

I. Take 1-295 to Portland.

2. Take Exit 7, Franklin Street.

3. Follow Franklin Street for approximately $1 / 2$ mile. At the 5th traffic light, turn left onto Middle Street.

4. Turn left onto India Street.

5. Turn right onto Newbury Street.

The Shipyard Brewing Company is on the right at 86 Newbury Street, just behind The Village Cafe.

Tour Information \& Gift Store I-800-BREW-ALE (273-9253) www.shipyard.com

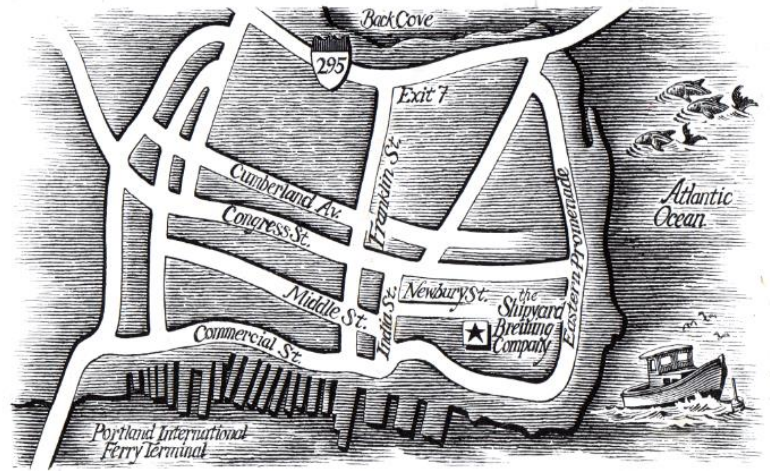

Figure 5. Shipyard Export

- Heritage and history combine in this regional brewery's carton. Brand name, beer name, and nautical imagery communicate a sense of place through maritime commerce instead of nature. An archaic ship, colonial architecture (e.g., a traditional saltbox house), and an old-fashioned artistic style reinforce the history of place. The map provided (see detail) helps guide visitors to the brewery in Portland, Maine. 


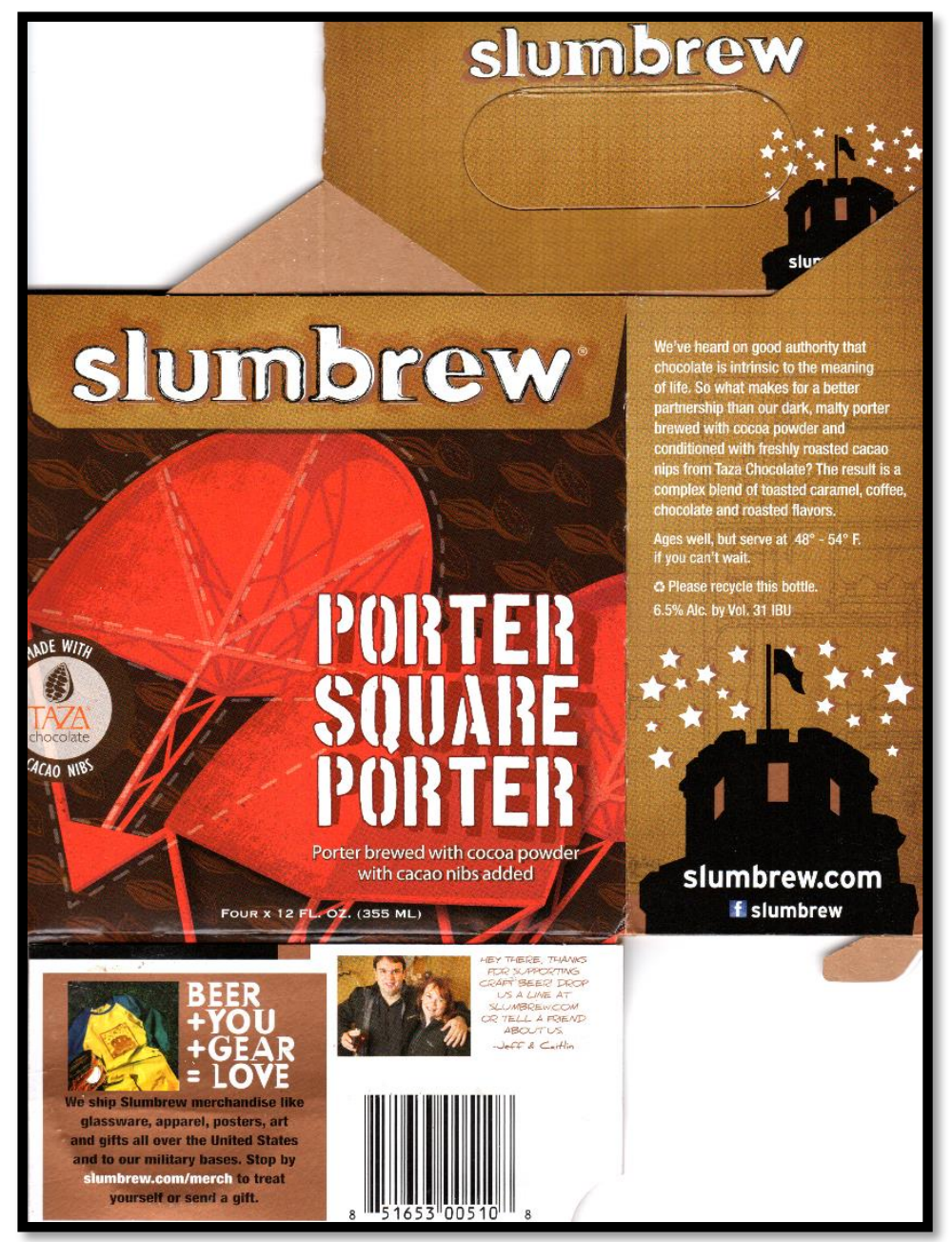

We've heard on good authority that

chocolate is intrinsic to the meaning

of life. So what makes for a better

partnership than our dark, malty porter

brewed with cocoa powder and

conditioned with freshly roasted cacao

nips from Taza Chocolate? The result is a

complex blend of toasted caramel, coffee,

chocolate and roasted flavors.

Ages well, but serve at $48^{\circ}-54^{\circ} \mathrm{F}$.

if you can't wait.

\& Please recycle this bottle.

$6.5 \%$ Alc. by Vol. 31 IBU

(detail)

Figure 6. Slumbrew Porter Square Porter

- Microbrewery cartons often contain local references that are unfamiliar to out-oftowners. The company name derives from 'Slummerview,' a derogatory nickname for the brewery's location (Somerville), while a local building and art installation are included as well. The product is humanized with a photo of the brewery's owners and a personal, signed note to the consumer that seems handwritten. 


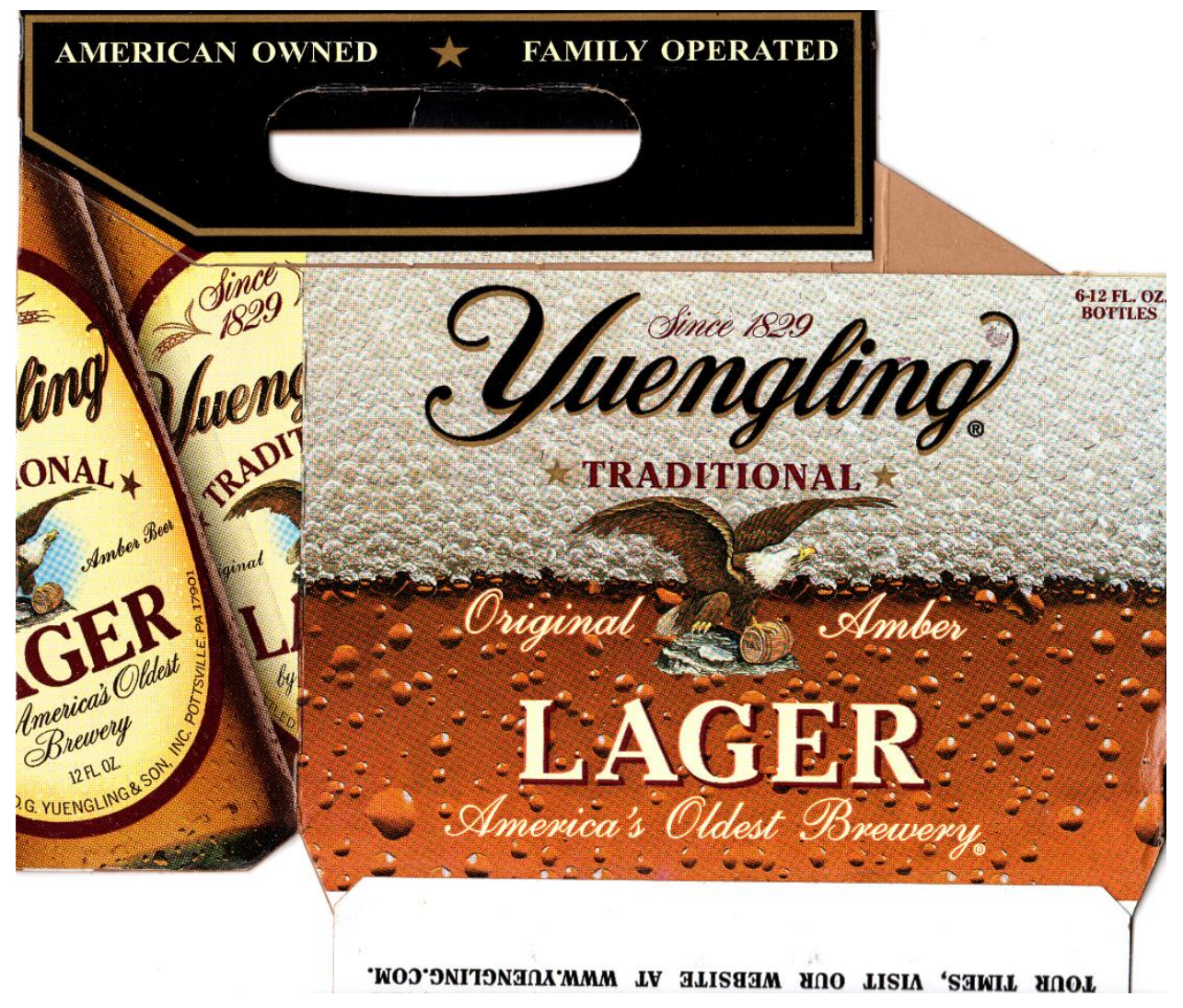

Figure 7. Yuengling Lager

- This large brewery implies a connection to the United States as a whole with its eagle, stars, and various texts ("America's Oldest Brewery" is also "American Owned"). Its claim to being "Traditional" suggests a craft dimension, while other elements reflexively communicate the brand itself (i.e. product name indistinct from brand name, replication of bottle image on carton). 


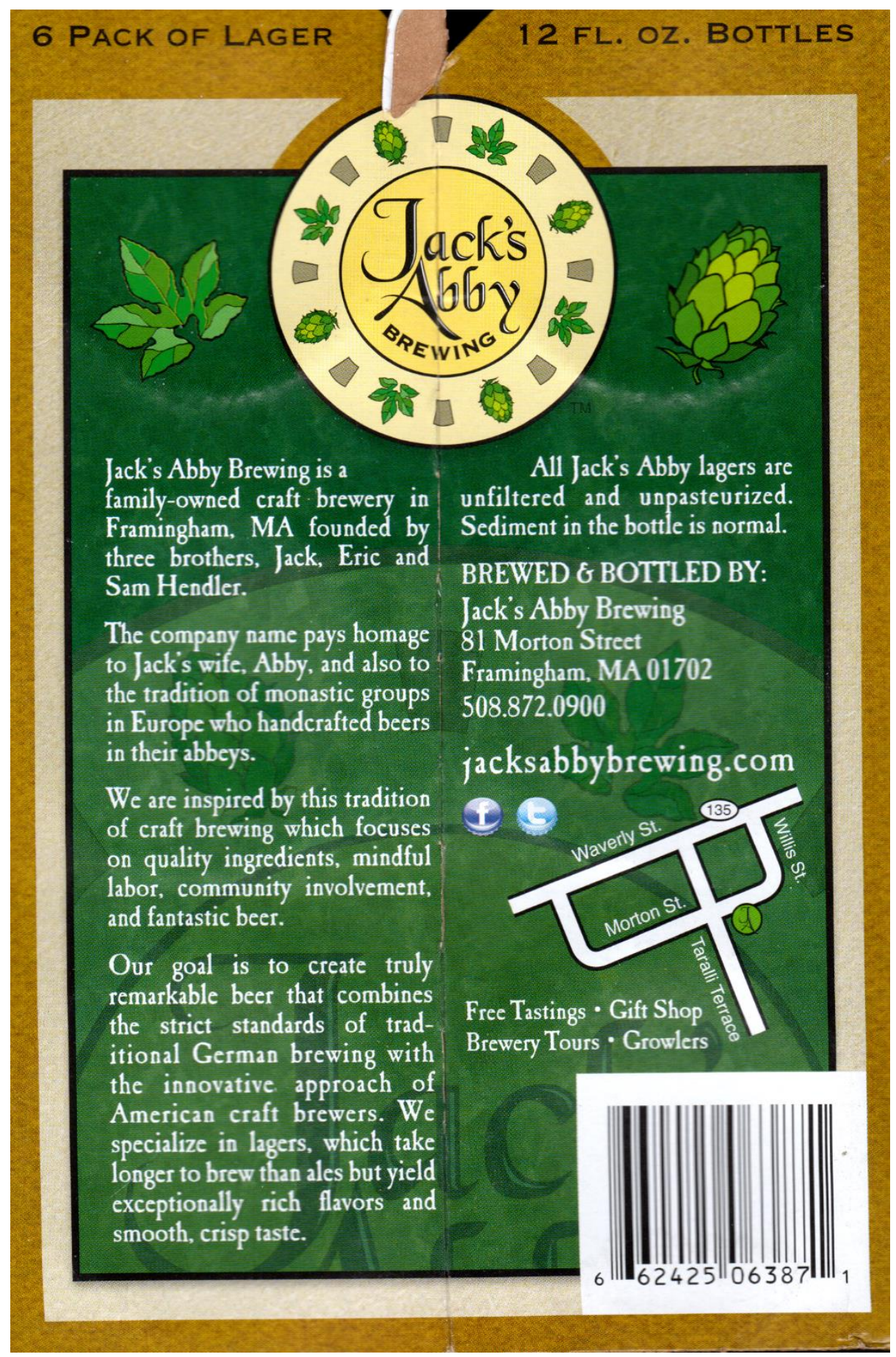

Figure 8. Jack's Abby Smoke \& Dagger (carton bottom)

- The narrative on the bottom of this regional brewery's carton effectively communicates humanization (the company is named after the wife of one of three brothers who are owners) and craft (they use traditional methods and a lengthy brewing process, and provide detail on product ingredient and characteristics). Images of a hop flower and leaf reinforce the craft dimension while a map guides prospective visitors to the brewery. 


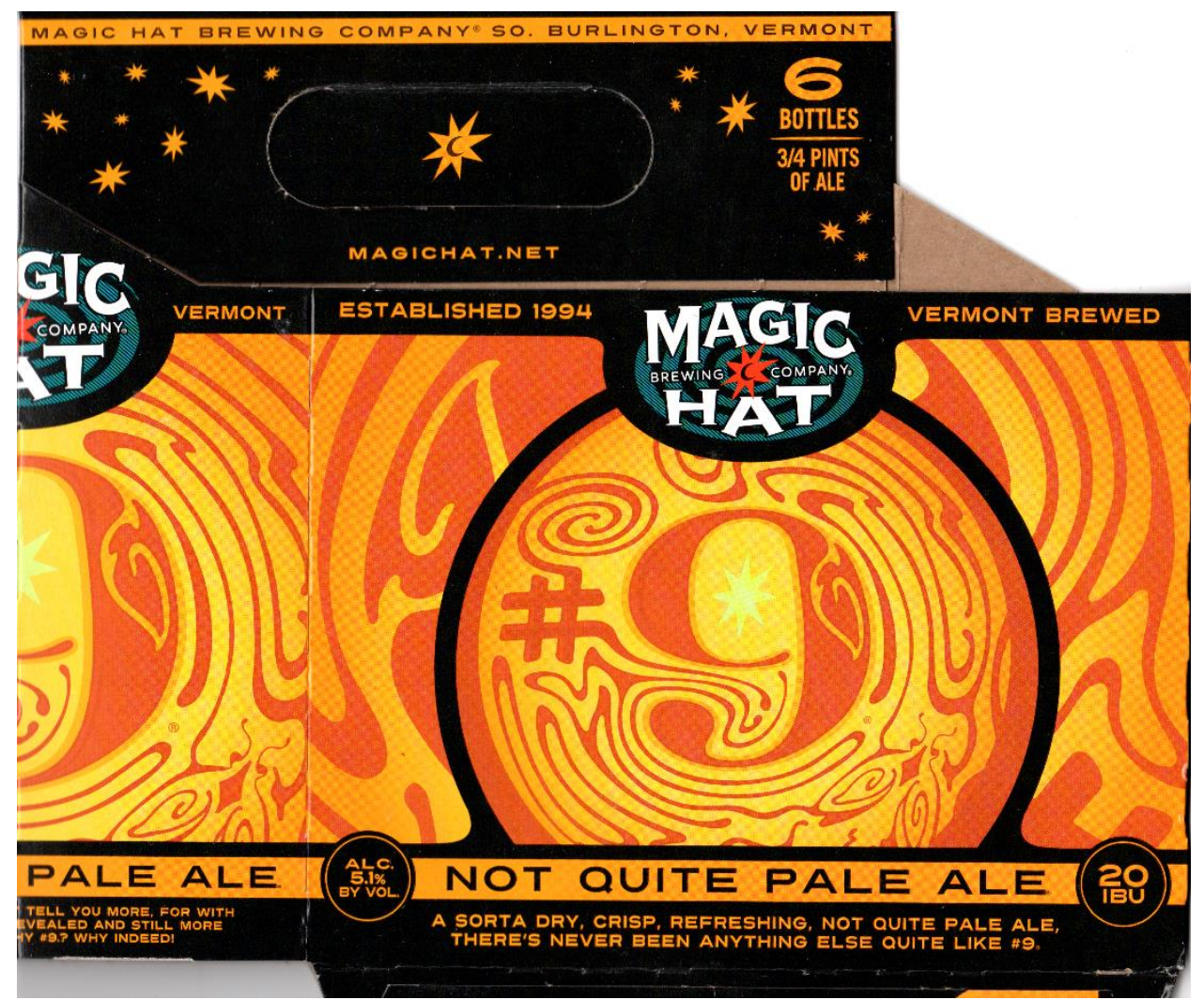

Figure 9. Magic Hat \#9

- This regional brewery's distinctive theme of mystery distinguishes it from other brands with more common themes. The brand name explicitly invokes "magic," which is reinforced through various images (moon, starbursts, and swirl designs), a vague statement about the indescribable beer, and the mystery of why it is called "\#9." 
Table 1. Average The me Use by Firm Size

\begin{tabular}{lrrr|r}
\hline \hline & \multicolumn{1}{c}{ Large } & Regional & \multicolumn{1}{c}{ Micro } & \multicolumn{1}{c}{ Total } \\
\hline Place-based & 1.55 & $\mathbf{3 . 6 9}$ & 2.88 & 2.68 \\
& $(1.56)$ & $(1.35)$ & $(1.66)$ & $(1.73)$ \\
Humanized & 0.73 & 1.38 & $\mathbf{1 . 4 9}$ & 1.27 \\
& $(0.77)$ & $(1.15)$ & $(1.55)$ & $(1.36)$ \\
Craft & 0.23 & $\mathbf{1 . 3 1}$ & 1.18 & 0.98 \\
& $(0.53)$ & $(0.79)$ & $(0.87)$ & $(0.89)$ \\
Distinctive & 0.23 & 1.56 & $\mathbf{1 . 7 6}$ & 1.33 \\
& $(0.53)$ & $(2.50)$ & $(2.0)$ & $(1.97)$ \\
Reflexive & $\mathbf{3 . 7 3}$ & 0.94 & 0.55 & 1.4 \\
& $(0.94)$ & $(1.12)$ & $(0.67)$ & $(1.57)$ \\
\hline $\mathrm{n}$ & 22 & 16 & 51 & 89 \\
\hline Note: Standard
\end{tabular}

Note: Standard deviation in parentheses

Table 1. Average Theme Use by Firm Size

Table 2. Average Scale of Place-based Themes by Firm Size

\begin{tabular}{lrrr|r}
\hline \hline & Large & \multicolumn{1}{c|}{ Regional } & \multicolumn{1}{c}{ Micro } & \multicolumn{1}{c}{ Total } \\
\hline National & $\mathbf{0 . 5 9}$ & 0.06 & 0.04 & 0.17 \\
& $(1.05)$ & $(0.25)$ & $(0.20)$ & $(0.59)$ \\
Regional & $\mathbf{0 . 5 5}$ & 0.25 & 0.22 & 0.31 \\
& $(1.14)$ & $(0.58)$ & $(0.78)$ & $(0.86)$ \\
State & 0.00 & 0.44 & $\mathbf{0 . 4 7}$ & 0.32 \\
& $(0.00)$ & $(0.73)$ & $(0.86)$ & $(0.72)$ \\
Local & 0.45 & $\mathbf{2 . 5 0}$ & 2.10 & 1.78 \\
& $(0.96)$ & $(1.55)$ & $(1.75)$ & $(1.73)$ \\
\hline $\mathrm{n}$ & 22 & 16 & 51 & 89 \\
\hline Note: Standard deviation in parentheses & &
\end{tabular}

Table 2. Average Scale of Place-based Themes by Firm Size 